\title{
Private Provision of Highways: Economic Issues
}

\author{
Kenneth A. Small \\ University of California at Irvine
}

February 5, 2009

Author contact information:

Department of Economics

University of California at Irvine

Irvine, CA 92697-5100

USA

tel: $+1-949-824-5658$

fax: +1-949-824-2182

ksmall@uci.edu

JEL codes: H44, H54, L91, R42

Keywords: privatization, road finance, toll road, road pricing

Acknowledgment: This author is grateful to the Show-Me Institute, St. Louis, Missouri, for financial support, and thanks Dan Bogart, Germà Bel, Alexander Galetovic, Joe Haslag, Chris Nash, and Clifford Winston for helpful comments. All facts and opinions expressed are the sole responsibility of the author. 


\title{
Private Provision of Highways: Economic Issues
}

\begin{abstract}
This paper reviews issues raised by the use of private firms to finance, build, and/or operate highways - issues including cost of capital, level and structure of tolls, and adaptability to unforeseen changes. The public sector's apparent advantage in cost of capital is at least partly illusory due to differences in tax liability and to constraints on the supply of public capital. The evidence for lower costs of construction or operation by private firms is slim. Private firms are likely to promote more efficient pricing. Effective private road provision depends on wellstructured franchise agreements that allow pricing flexibility, restrain market power, enforce a sound debt structure, promote transparency, and foster other social goals.
\end{abstract}

\section{Introduction}

Privately owned or operated roads, once common but largely phased out over the twentieth century, are making a startling comeback. Spain, Portugal, Italy, and France have recently converted their high-speed intercity expressways to mostly private systems. The UK and Finland, among other countries, have taken steps in that direction; Australia and Canada have important private road projects; even in Latin America, privately built and operated toll roads are not unusual. ${ }^{1}$

In the United States, privatization has moved more slowly, but nonetheless is gathering momentum. New roads have been privately financed in California, Virginia, and Texas, while existing public toll roads have been privatized in Illinois and Indiana, with other states sharply debating whether to follow suit. Much of this activity proceeds opportunistically, but in 2004

\footnotetext{
${ }^{1}$ See Joint Transport Research Centre (2008), especially sect. 2.5 and Annex. Gómez-Ibáñez and Meyer (1993, ch. 7-11) describe earlier experience.
} 
Texas adopted a plan (subsequently delayed) to systematically integrate private highway builders and operators into future highway expansion. ${ }^{2}$

What accounts for this revival? The most potent factor is public-sector financial difficulties and, especially in the US, heavily reliance on the shrinking tax base of fuel purchases. A second factor is experience with privatization and deregulation of other types of public services such as electricity, water, and mass transit. A third is the desire to lower the cost of providing highway infrastructure. A fourth factor is urban congestion, the intractability of which leads policymakers to look for alternatives to "business as usual;" those alternatives include pricing, which in turn makes private provision more natural.

Each step toward private involvement raises public concern about numerous issues such as toll rates, market power, risk bearing, cost overruns, bankruptcies, public bond ratings, use of revenues, and uneven application of tax provisions. Most of these are economic matters amenable to objective analysis, but they are complex and answers are not always definitive.

The purpose of this paper is to review the main economic issues involved in private provision of roads. It does not seek a "winner" in some overall debate about privatization; rather, it is aimed at identifying the factors that determine whether any given private initiative is in the public interest. The analysis takes advantage of accumulating experience with private provision of highways in order to formulate some general principles.

I take private provision of roads to mean the use of private firms for substantial parts of decision-making and finance — roughly what is covered by the loose category called "public private partnerships" (PPPs). ${ }^{3}$ Examples of private decision-making roles within PPPs include

\footnotetext{
${ }^{2}$ Forsgren and Macdonald (2005) provide a more detailed recent US history.

${ }^{3}$ Standard \& Poor's defines a PPP as "any medium- to long-term relationship between the public and private sectors, involving the sharing of risks and rewards of multi-sector skills, expertise, and finance to deliver desired policy outcomes" (Forsgren and Macdonald 2005, p. 46).
} 
design, finance, construction timing, setting of price schedules, charging and enforcement, public relations, and emergency response services. In order to provide concrete institutional context, I focus especially on the United States, where the requirements for maintaining and further expanding a network worth perhaps $\$ 1.7$ trillion are overwhelming the current financing system, built primarily around fuel taxes that raised just $\$ 72$ billion in $2007 .{ }^{4}$

\section{Basic Issues: Capital, Financing, and Incentives}

The most basic issues that distinguish capitalism as a form of economic activity are those governing disposition of capital and the resulting incentives on economic actors. Unsurprisingly, these same issues are at the heart of the cases for and against private road provision. They include the sources and costs of investment funds and issues of risk bearing, efficiency, and innovation.

\section{$2.1 \quad$ Sources of funds}

As noted, a prime motivator for private road provision is that the public sector is short of funds. In several cases, PPPs have dramatically speeded up desired investments. Is this a genuine advantage of the private sector, or is it just an accounting anomaly?

Ultimately, the availability of investment funds for infrastructure depends on the economy's savings rate and on decisions allocating those savings to specific sectors. One could argue that citizens desiring improved infrastructure should be equally willing to tax themselves or to encourage private investment funds to flow from other sectors of the economy.

However, there are practical constraints on the public sector's ability to respond to

\footnotetext{
${ }^{4}$ Small and Verhoef (2007), p. 112; US FHWA (2008), Tables MF-1, FE-9.
} 
citizens' investment priorities. Restrictions on debt finance may prevent state and local governments from borrowing, even to finance projects that would eventually pay for themselves through tolls. Instead, investment often depends on current tax proceeds, making it difficult to accommodate fluctuating investment needs. To some extent, such debt restrictions can be overcome through inter-governmental transfers from a higher level of government; but national governments also are politically limited, as illustrated vividly by the excruciating negotiations over recent re-authorizations of US federal highway programs.

The private sector, meanwhile, has sources of investment funds that are particularly well matched to road projects, especially pension funds and holdings of insurance companies. Managers of these funds need long-term investments with relatively stable returns, and consequently have contributed importantly to the boom in private finance of road investments.

Thus, one can reasonably argue that the private sector is a legitimate way to expand the public's ability to finance desired road investments. A proviso is that the public sector could in principle provide such financing itself, and perhaps would do so through some political process if the private option were unavailable.

\subsection{Cost of capital}

An oft-cited drawback of private finance is that the private sector has to pay more for its capital than does the public sector. There are several factors behind this cost differential, especially taxes, risk-bearing, and debt structure. In assessing them, it is important to consider all the social costs, not just the financial cash flows. 


\section{$\underline{\text { Taxes on capital }}$}

From the point of view of a state or local government in the US, the federal tax exemption of interest payments on state and local bonds is clearly an important cost saving, often highlighted in comparisons of public and private options. In 2005, this exemption was extended selectively to certain private road ventures as well, through the mechanism of tax-exempt Private Activity Bonds.

However, the tax-free status of a bond is not a social saving in comparison to taxable forms of finance. Rather, it represents a shift of certain capital costs from the project-specific account to a general governmental-revenue account. A social-cost comparison can be accomplished by subtracting from the private costs any tax payments included in them, inflated to account for the "dead-weight loss" of raising those tax revenues through some other means. This dead-weight loss is a measure of how much consumers must ultimately give up, due to higher prices and/or less efficient production, in order to finance each dollar of tax revenue at the margin. Empirical work suggests it is typically around 15 percent of tax revenue collected in the US, and 15 to 190 percent across various European nations with different marginal tax rates. ${ }^{5}$

Another important tax consideration is generous income-tax deductions for depreciation of private capital investments meeting specific criteria. In this case the provisions favor private finance, because the deductions are much larger than the economic value of depreciation actually experienced on the assets. Indeed, a major motive for the recent private purchases of toll-road leases in Chicago and Indiana was the ability of private investors to realize such depreciation deductions. In order to make a valid comparison of social cost, these private tax savings (again

\footnotetext{
${ }^{5}$ See Parry and Oates (2000) for a more complete discussion of dead-weight loss, and Small and Verhoef (2007, pp. 147, 177-178) regarding applications to transportation. For Europe, see Klevin and Kreiner (2006), especially Table 3, columns S5-S8.
} 
adjusted for dead-weight loss of raising public revenues) need to be added to the private cost of capital, just as tax liabilities need to be subtracted.

\section{$\underline{\text { Risk-bearing }}$}

Road investments involve considerable uncertainty regarding construction cost, operating costs, traffic levels, future regulations, and other key determinants of economic returns. The resulting "risk premium" raises the return needed to attract investors to markets for private capital, but usually not to those for public capital except in times of unusual fiscal difficulties.

But does this difference mean that the public sector is inherently better at bearing the risks posed by these uncertainties? To address this question, it is important to distinguish between pure (uncontrollable) risk and "controlled" risk, where the party has some ability to influence the uncertain incomes. (The latter is called "moral hazard" in the insurance industry.) We consider pure risk here, and controlled risk in Section 2.3.

Aversion to pure risk arises from problems created by being unable to predict the outcome of one's affairs. For example, private individuals are risk averse when undertaking large investments if an uncertain outcome may greatly affect their standard of living. Similarly, small firms are often risk averse because the managers' or owners' livelihoods depend heavily on the firm's earnings. These risks are often reduced by pooling diversified projects, as in the case of a large firm or a diversified investment pool such as a pension fund. Even a small firm may show little risk aversion if its owners can diversify their portfolios elsewhere and its managers are rewarded for risk-taking.

The public sector can in principle diversify its projects almost infinitely. Thus the national governments of most developed nations can issue bonds with virtually no risk premium. 
(This is not true for many less developed nations, due to financial problems including past defaults.) But the same factors that limit direct government investments also limit governments' risk-bearing ability. Citizens are not necessarily prepared to give carte blanche to their elected leaders to cover cost over-runs or other adverse outcomes of risky projects, in part because they do not trust those leaders to always act in the public interest. Furthermore, in a federal political system, state and especially local governments are subject to considerable fluctuations in fiscal health due to national and regional economic factors. Even worse, project risks are often positively correlated with those same factors, as for example when a recession causes toll revenues to dry up just when local tax revenues are running short.

The problem of lack of trust in leaders is actually quite general in both public and private organizations, although its magnitude may differ between them. Suppose taxpayers or shareholders are well diversified in their overall investments, and thus not really concerned with the uncertainty over one particular project. They would then like their managers to invest if a project's expected rate of return is greater than the applicable cost of capital. However, a typical project manager is much less diversified in terms of the portfolio of professional projects with which he or she is associated. If the project turns out to be a bad one, that manager's reputation may be damaged regardless of fault. Thus this individual manager may exhibit greater risk aversion than the stakeholders. Well-run organizations attempt to compensate for this effect through incentives to encourage appropriate risk-taking, but they are difficult to implement in such a way as to have just the right effect.

For all these reasons, there are genuine barriers to full diversification even by large government bodies, potentially causing citizens and/or officials to shun risks. The aversion to these risks is a social cost, just like the risk premium in private capital markets. However, this 
social cost is not reflected in the market interest rate on government debt because the government can compel taxpayers to cover defaults. Instead, the social cost is reflected in a shortage of public funds for projects that would be warranted under the observed market rates precisely as argued in Section 2.1. A calculation of the social cost of capital, for purposes of comparing public and private provision, should then include a "shadow value" reflecting this scarcity of funds. Another way to view the same point is that the projects for which a given proposal competes for scarce public funds will tend to have rates of return that are higher than interest rates on government debt, and it is these higher rates that constitute the social cost of capital for the project under consideration. ${ }^{6}$

The current state of knowledge does not enable us to say whether this extra shadow value of publicly raised capital is as great as the risk premium required by the private sector. In practice, the tax-adjusted difference in observed interest rates provides an upper limit to the relative advantage of the public sector in cost of capital; the actual advantage is probably considerably less.

\section{$\underline{\text { Debt structure }}$}

A private firm's mix of debt and equity, and the term structure of its debt, have important influences on the firm's cost of raising capital. A highly leveraged structure, i.e. one with a high rate of debt to equity, is cheaper for the firm but creates a greater chance of bankruptcy. This is

\footnotetext{
${ }^{6}$ This view is similar but not identical to that expressed by Klein (1997) and Irwin (2007, pp. 65-66). They argue that the true cost of capital is the risk-free rate of interest plus a risk premium that depends only on the projectspecific risk, not on who bears it. Their rationale is that governments achieve low risk premiums by forcing taxpayers to guarantee payment for the project under consideration, and that these taxpayers therefore bear project risks for which they are not compensated. But this argument need not apply to the entire project-specific risk; some portion of it is in fact diversified through the tax system. Thus there is no reason to assume exact equivalence between social and private costs of capital.
} 
relevant to the public interest because the public may be severely disadvantaged if a private operator goes bankrupt. ${ }^{7}$

Public entities also need to pay attention to their amount of debt, because it affects their credit rating and creates obligations for future taxpayers. This raises a question concerning the sale of a long-term lease on an existing revenue-producing road, as illustrated by the Chicago Skyway and the Indiana Toll Road. Such a sale converts future revenues, occurring over an extended period, into an up-front single cash payment. One consequence is that some of the uncertainty over revenues is shifted to the private franchisee, an issue discussed in Section 2.3. Another is that the government receives a big block of capital funds in return for giving up future revenues - which is very similar to issuing debt, and indeed may be seen as a loophole in regulations restricting debt finance.

\subsection{Controlled risk factors}

When the outcome of a risk can be influenced by one of the parties involved with an infrastructure project, there is a considerable advantage in having that party bear the risk because it will then have an incentive to make efficient tradeoffs between adverse outcomes and the costs of avoiding them. For example, if a private firm bears the risk of cost over-runs, then it will work to assure that its design and construction strategies account for the effects of unexpected events on costs.

The same example, however, illustrates the complexity of incentives. Some cost-cutting measures available to a private firm might reduce the quality of its product in ways that cannot easily be detected until later. Examples are legion in the construction industry: poorly mixed

\footnotetext{
${ }^{7}$ Furthermore, debt structure often is changed following the conclusion of a franchise, as the franchisee seeks to restructure its finances - usually in the form of more leverage in order to reduce its cost of capital.
} 
cement, inadequate steel reinforcing bars, substandard electrical wire or plumbing. A good franchising process will attempt to control this kind of undesired cost-cutting, perhaps through quality specifications, inspections, and the use of reputation as a selection criterion. Another way to control it is to combine construction and operation into a single long-term franchise so that the firm itself would suffer the consequences of poor-quality construction — thereby perhaps expanding the scope of privatization. If none of these control strategies are feasible, a cost-plus contract, rather than a PPP, may be the best available option even if it entails some inefficiency. Irwin (2007) points out two important additions to the principle of assigning risk to the party best able to control it. First, even events outside anyone's control can be handled in ways that make them more or less costly; a good franchise agreement will assign the risk accordingly. For example, a project designer may be able to minimize damage due to the risk of an earthquake, whereas the government may better be able to minimize the damage from economic fluctuations. Second, it is unhelpful for a private franchisee to bear a controlled risk if it lacks authority to implement efficient responses to that risk. Nash (2005) provides an example from UK road franchises, in which the franchisee was paid on the basis of the amount of traffic generated, thereby shifting the traffic risk to the private sector. But the government retained the power to build competing roads and restricted the franchisees' ability to build interchanges that might generate traffic, thereby nullifying most of the potential incentive effects from shifting the traffic risk. As another example, some traffic risk may be effectively absorbed by a franchisee with authority to build a road in increments rather than all at once (Irwin 2007, p. 59).

This brings us to the question of who can best bear the risk posed by uncertain future traffic projections. Such uncertainty arises from several sources. One is unknown competing services, which are most often under control of a highway authority. Another is land-use and tax 
policies, which are under control of local or higher-level governments. A third is the health of the local economy, which is under some limited control by both local and national governments through economic policies. A fourth is the fact that demand depends also on factors controlled by the operator, such as ride quality, ease of toll collection, and marketing policies. To complicate matters further, some such factors might be privately profitable but socially counterproductive: for example, political maneuvering to prevent competing investments. This brief review suggests that an ideal arrangement will allocate traffic risks in rather complex ways.

Finally, there is the risk of political manipulation or changes in contractual terms, which are real possibilities unless contracts carefully specify the franchisee's rights. Spiller (2008) argues that politically motivated opportunism, especially as may be instigated by outside parties with their own interests at stake (e.g. competitors for the contract), require that public-private contracts be more complete and rigid than contracts between two private parties.

One advantage of the franchise process is that it creates the possibility for sophisticated allocation of risk through formulas or other provisions. For example, most franchise agreements limit future toll rates using a formula involving inflation and/or some measure of economic activity. Some specify sharing of revenue surpluses or shortfalls compared to projections. Others, especially in the UK, do not even use real tolls but compensate the franchisee using public payment of "shadow tolls," i.e., payments proportional to the amount of traffic. These schemes enable the public entity designing the franchise to allocate traffic risk in a rather flexible manner. By contrast, public operation places most traffic risk on future taxpayers and/or future users, with the mix depending on how toll rates will be adjusted; whereas complete privatization places traffic risk fully on the private firm and on any creditors or citizens who would suffer from a private firm's bankruptcy. 


\subsection{Cost efficiency}

One of the hoped-for advantages of private involvement is that private firms will be more efficient, thereby lowering the cost of constructing and operating roads. There are several possible reasons. Private firms have stronger financial incentives because costs come out of their own profits. They are less prone to political interference in economic decisions, and they operate under fewer rules regarding procurement, civil service, union bargaining, affirmative action, and so forth — which may serve valid social purposes but also impose some cost.

In the case of private highways, does the evidence support this expectation of lower costs? There are some anecdotal examples — for example, in France in the 1980s, the private firm Cofiroute exhibited lower unit construction costs than its publicly owned counterparts (Gómez-Ibáñez and Meyer 1993, p. 201). However, there is little confirmation of such differences from systematic evidence.

Rather, there is some evidence about a related quantity, cost and time overruns. Allen Consulting Group (2007, Table 4.1) examines 54 Australian projects ( 25 of them in transportation) and finds that PPPs had smaller discrepancies between actual costs and those specified in the initial contract. There was also a small reduction in time over-runs (Allen Consulting Group 2007, Table 4.3). The problem with such comparisons is that the costs and times specified in the contracts were themselves probably affected by whether or not a PPP was involved. For example, public authorities may have been forced by privatization to more carefully specify the nature of a project, in which case smaller overruns reflect better estimates rather than cost savings. Furthermore, the possibility of overruns in traditional cost-plus contracts provides some flexibility to the public sector, allowing it to expedite contracting while design 
details are being worked out and to respond to unexpected changes in conditions during construction. As noted by Dewatripont and Legros (2005), some cost overruns can be expected as an equilibrium phenomenon even in an efficient contracting system.

Thus it appears that the conclusion of Gómez-Ibáñez and Meyer (1993) still holds: “experience provides only limited support for the enhanced [cost] efficiency of [road] privatization" (p. 201). They suggest that private roads might not achieve the kinds of efficiency gains seen in other sectors because the bidders are already strongly involved in public procurement, and therefore do not realize any additional gains from experience or scale. Still, Gómez-Ibáñez and Meyer think that some modest efficiency gains are likely, due to greater flexibility and innovation in design, even though this remains unproven.

Elsewhere in the transportation sector, there is evidence of somewhat greater efficiency advantages of private operators. Bus transit is a case in point. ${ }^{8}$ A typical finding is that private bus firms operate with 20 percent lower costs, although some of this is through lower wages rather than increased efficiency. (Lower wages represent efficiency gains only if they reflect use of more appropriately-skilled labor.) But there is also wide variation within each sector. The primary factor affecting costs in bus transit appears to be less the form of ownership than the types of management incentives used (Perry, Babitsky, and Gregersen 1988). Thus to achieve cost efficiency, it may be more important to design good management incentives than to rely on privatization.

\footnotetext{
${ }^{8}$ For reviews see Gómez-Ibáñez and Meyer (1993), especially ch. 2-6, 13; Preston (2005); Karlaftis (2008); and Small and Verhoef (2007, sect. 6.3).
} 


\subsection{Innovation}

Private operators sometimes propose innovative solutions for difficult social problems that can also be viewed as business opportunities. For example, deregulated railroads negotiated long-term contracts that greatly expanded the types of service provided to shippers. Deregulated telecommunications firms accelerated the use of microwave relay stations for long-distance telephone communications, as well as building cellular networks and offering numerous datatransmission services.

Is there scope for similar advances in highway networks? On the face of it, highways may seem less ripe for innovation. Yet there are surprising examples of creativity. Cofiroute, a private French company with worldwide toll road experience, is completing the A86 outer ring road around Paris using a tunnel under the Versailles palace. In order to provide the most congestion relief possible at reasonable cost, the tunnel will be restricted to autos and will use narrow lanes and short overhead clearances, with a consequently low speed limit of 42 miles per hour. ${ }^{9}$ This kind of breakthrough could be difficult for a public agency, bound by standards and protocols, to achieve.

The greatest innovations may come in the form of pricing. It was a private consortium that proposed and implemented the toll schedule for California's State Route 91 express lanes, the first US example of time-varying tolls for congestion management. Private firms have also promoted innovations in toll collection technology. As discussed later, pricing innovations could be an important contribution to efficiency in urban highway operations.

\footnotetext{
${ }^{9}$ See Poole (2006, pp. 28-31) for discussion of this and other urban congestion-relief tunnels.
} 


\subsection{Other issues}

One concern sometimes raised about private toll roads is that users are already paying for roads through fuel and other taxes, and now are asked to pay again through tolls. This critique, which applies equally to publicly operated toll roads, is most applicable if the arrangement is structured so that tolls cover the cost of the road. In that case, any fuel tax meant also to cover road costs should ideally be refunded so as to create a more "level playing field" between the private and public sectors. However, the practical significance of the problem is small. User charges, including fuel and vehicle taxes, do not fully cover the cost of roads in the US, and certainly peak-period user charges don't come close to covering the capacity cost of major urban roads. Furthermore, user charges (such as the fuel tax) can also be considered to be externality charges to compensate for the fact that drivers do not fully bear the costs of congestion, pollution, and motor vehicle accidents resulting from their individual decisions (Parry and Small 2005). Thus, it is somewhat subjective to argue that a given tax payment helps "pay for" the road on which it is generated.

Another issue is how the public sector will use the revenues. As already noted, the sale of a long-term lease is similar to issuing public debt; therefore it is legitimate to insist that some political mechanism be in place, as in common when issuing debt, to direct the revenues to appropriate uses over a time period comparable to the duration of the lease. The lease of the Indiana Toll Road and the proposed lease of the Pennsylvania Turnpike appear to meet this criterion by putting funds into infrastructure accounts; the lease of the Chicago Skyway did not have comparable provisions. An even tighter restriction, namely that toll revenue be used only for investments in that same highway corridor, is sometimes suggested but would be inefficiently 
restrictive because there is no reason why the highest priority for investment should be in that same corridor.

\section{Pricing}

One of the most widely held views of professional economists about transportation is that the way users typically pay for public roads serves the public interest very poorly. Prices are much too low for highly congested roads and do not vary in a helpful way with time of day. One of the innovations accompanying private road provision has been some move toward pricing that takes congestion into account. ${ }^{10}$ This raises the question: can the private sector do a better job of designing and implementing efficient pricing structures? To investigate this question, we need to consider market structure and regulation, with special attention to priced express lanes.

\subsection{Market structure and pricing}

Some theoretical results are helpful as starting points. First, it is clear that a profitmaximizing road owner would use congestion pricing if possible. To be more precise, such an operator would vary prices by time of day according to changes in the marginal social cost due to congestion — that is, in a manner similar to the time-varying pricing that would maximize economic efficiency. The reason is that the owner has an incentive to make the road as valuable as possible to its users, as they are then willing to pay higher tolls; it can do this by offering good service quality, including low congestion. However, the profit-maximizing operator would add a markup to marginal social cost reflecting the same consideration as a monopolist in any other

\footnotetext{
${ }^{10}$ The US Department of Transportation has given such pricing schemes high priority in its use of various demonstration programs authorized by Congress since 1990, the latest of which - the Urban Partnerships Program — offers large grants to local regions willing to try out some form of congestion pricing. See US DOT (2008a). For
} 
market: namely, the less users are willing or able to switch to other options, the greater the markup. ${ }^{11}$

These observations lead directly to two policy conclusions. First, private operators are indeed likely to seek to implement innovative and beneficial pricing structures, as noted also by US GAO (2008, pp. 24-25). But second, private operation will often need to be accompanied by regulation to keep overall price levels from becoming excessive. An example is provided by the privately built and operated M6 Toll Road in the UK, which enables vehicles to bypass Birmingham while traveling between London and Liverpool or Manchester. The toll is unregulated, and the resulting high toll has been criticized for undermining the road's congestion-relief goals. Price regulation is discussed in Section 4.1.

Thus, it seems likely that in realistic situations, the private sector would often adopt congestion pricing in some form. In some situations, especially where a new road is being financed privately, the public may accept novel pricing arrangements more readily from a private than from a public operator. These conclusions are nicely illustrated by the experience with several private toll-road franchises in Santiago, Chile, all of which operate with time-varying prices and appear to be relatively well accepted.

\subsection{Priced express lanes}

One innovative pricing opportunity is the private finance, construction, and operation of special express lanes that parallel a congested road and operate at higher speeds, available for a

reviews of congestion pricing, including the rationale, see Small and Verhoef (2007, ch. 4) and papers in Santos (2004).

${ }^{11}$ See Small and Verhoef (2007, sect. 6.1.1) for a precise statement and demonstration. The markup is inversely proportional to the absolute value of the demand elasticity. The situation is more complex when two or more private road owners compete; de Palma and Lindsey (2002) confirm that private operators have some incentives to 
price which varies by time of day. In most cases these express lanes operate as "High Occupancy Toll" (HOT) lanes, in which carpools go for free (or sometimes at a reduced price) and other vehicles pay the toll. An example is the "91 Express Lanes" in Orange County, California, part of State Route 91; these express lanes were proposed, built, and initially operated by a private consortium under the first modern US legislation fostering private road projects. ${ }^{12}$ Other examples include recently opened HOT lanes in Colorado, planned HOT lanes on the Washington Beltway in northern Virginia, and several projects in the Trans-Texas Toll Corridor for which proposals were solicited beginning in 2004. In addition, public agencies have opened HOT lanes in the San Diego, Minneapolis, and Seattle areas. The US Department of Transportation actively encourages such projects through its Express Lanes Demonstration Program (US DOT 2008b).

These examples raise two questions. Are such express lanes an efficient policy by themselves? And might they lead toward a fuller application of economically-based pricing tools?

The answer to the first question depends on how diverse people are. If people vary widely in the values they assign to time savings, then they may sort themselves into two groups, both of which benefit from the express-lane scheme: one group with high time values using the toll lanes, and one with lower values using the free lanes. This is an example of offering differentiated products, similar to what happens in many consumer-oriented industries. If, by contrast, most people have similar time values, then the small gains from offering differentiated products may be overcome by the efficiency loss of inherent in two roadways failing to

introduce time-varying prices, but find that these incentives may be thwarted by fear of provoking a price cut by a rival.

12 The legislation was California Assembly Bill 680 (AB680), in effect from 1989 through 2002. See Sullivan (2006) for a detailed account of the 91 Express Lanes. 
equilibrate. Simulations show that if users are homogenous and the express price is set at a profit-maximizing level or at a level designed to make the express lanes congestion-free, too many will use the regular lanes, making them more congested than necessary and causing overall welfare losses compared to no pricing. ${ }^{13}$ However, preliminary evidence from State Route 91 suggests that value of time does in fact vary greatly across users, and even across trips taken by a given user. ${ }^{14}$

The second question is one of political economy. If private initiatives accustom motorists to the idea of paying extra for faster travel, and people see the implementation and charging technology working in practice, will they be amenable to more far-reaching pricing schemes? The evidence is far from clear, but it seems possible. Public acceptance of nearly all pricing schemes has increased as people get used to them and see their effects (Zmud and Arce 2008). Following California's privatization initiative in 1989, the state of Washington passed similar legislation and the state's transportation commission approved several proposals for implementation, including one that would gradually turn lanes on Interstate 5 into express lanes, one by one, until the entire freeway was priced. Although that proposal did not survive public scrutiny, it shows how far some political leaders were willing to go. Today, officials are going much further, exemplified by the mayor of New York City proposing a toll ring around all of southern Manhattan — clearly inspired by the success of toll rings in London and Stockholm. That proposal ultimately was approved by all but one of the necessary parties for implementation, the holdout being the New York State Legislature.

\footnotetext{
${ }^{13}$ Small and Yan (2001), Verhoef and Small (2004). Another factor is that some capacity is lost by dividing a road into two parts; see Lee (2008) for a quantification.

${ }^{14}$ Small, Winston, and Yan (2005); Sullivan (2000).
} 


\section{Franchising Arrangements}

One of the main arguments for private sector involvement in road provision is that effective competition "for the market" can be fostered at the time a franchise is awarded. Furthermore, the terms of the franchise can be structured to fine-tune the incentives, the degree of risk-sharing, and the division of economic returns between public and private sectors. Thus, the nature of franchise agreements and the procedures for awarding them are critical to obtaining public benefit from private participation. Such agreements involve technical matters of finance, and so require market sophistication within the public sector - something that is fostered by experience, creating one of the arguments for demonstrations and experiments.

Market power in private toll roads involves the same public policy issues as in any other industry, where such power is typically curtailed by anti-trust laws or regulated as in the case of electric utilities. Regulating a toll road is less complicated than an electric utility, but it still raises similar basic questions: should regulation specify prices, rates of return, performance standards, and/or required investments? To review the many issues surrounding these questions here would be prohibitive, but we can consider several that are most relevant for our topic. ${ }^{15}$

\subsection{Toll rates}

Most road franchises specify maximum tolls, usually in terms of a starting value and a formula for growth. This practice has the advantage of removing future toll changes from the political process - at least, that is the hope - but it also has problems. First, it removes pricing

\footnotetext{
${ }^{15}$ Gómez-Ibáñez (2003) and Guthrie (2006) provide excellent reviews of these issues as they pertain to infrastructure. A central theme is that regulating a monopoly is a variant of the more general problem of designing procedures to protect parties who are vulnerable to exploitation following irreversible investments in long-term assets whose value is specific to a particular relationship. Similarly, Laffont and Tirole (1993) consider the problem of relationship-specific assets to be central in analyzing optimal procedures for public procurement.
} 
flexibility and so may prevent an innovative pricing structure. Second, it requires projections of a desirable toll rate, possibly far into the future.

Theoretical and simulation studies have found that the public benefits from toll roads are quite sensitive to the toll rate, especially for long-term contracts. This is especially true when there are unpriced close substitutes, which is common and is sometimes even required as a condition for allowing a road to be tolled. When there are unpriced close substitutes, setting the toll too low will encourage excessive overall corridor traffic, while setting it too high will encourage an excessive fraction of that traffic to remain on the already congested free roads. The desire to attract traffic away from these free roads is often a special concern, because they are likely to be highly congested arterials serving local traffic, affecting noise and pollution levels in densely populated areas, and having a worse safety record than expressways.

An alternative to specifying the toll is to specify a maximum rate of return, as was the case with California's "91 Express Lanes," thereby giving the franchisee substantial pricing flexibility. ${ }^{16}$ The history of rate-of-return regulation of public utilities is not entirely encouraging. But one of its main problems - a tendency to encourage padding the capital base in order to increase allowed earnings (Averch and Johnson 1962) — is more easily controlled with roads than other types of utilities. This is because the capital stock of a road project is mostly in the road itself, whose characteristics can be specified readily. Thus, flexible pricing with an earnings cap remains a promising way to limit tolls within a private road franchise.

\footnotetext{
${ }^{16}$ The regulation for the 91 Express Lanes required that any profits exceeding those allowed be shared with the State of California. This is different from typical rate-of-return regulation of public utilities, which uses the allowed rate of return just as an intermediate step in calculating specific maximum prices (Guthrie 2006, sec. 2.1).
} 


\subsection{Profitability and subsidies}

A critical question for private highway finance is the financial feasibility of the initial investment. Under what conditions will building, operating, and pricing a highway be profitable?

One result is well known in the economics literature. If capacity is added and priced according to the theoretically ideal prescriptions of investment analysis and congestion pricing, then it will just pay for itself provided there are no scale economies or diseconomies in its construction. ${ }^{17}$ If road construction instead involves diseconomies of scale, as may happen in urban settings because of intersections and rising land costs (Small 1999), then the road would even more than pay for itself. However, in the common case where there are scale economies in construction, for example due to fixed costs resulting in more capacity than is strictly needed to handle the traffic, optimal congestion pricing will not cover the investment cost. Thus subsidies are needed, especially for the lower-volume, less financially attractive roads that may be desired to encourage regional integration and economic development.

The postwar experiences of France and Spain illustrate well these theoretical findings. ${ }^{18}$ Both began building their motorway networks using franchises to private firms, with no public funds. This worked well for the most heavily traveled routes, but proved an inadequate financial base for continued development of the networks. Due to this and other factors, both nations partially socialized the networks during the 1970 s, a process only recently reversed through new privatizations. The net result is that most of the motorway networks in France and Spain today are in private hands, but were built with substantial portions of public funds. These experiences are consistent with a conclusion of Forsgren and Macdonald (2005):

\footnotetext{
${ }^{17}$ Small and Verhoef 2007, sec. 5.1.1. There is another technical condition, which is that congestion formation also shows no scale economies or diseconomies, that is, congestion is a function only of the ratio of traffic volume to capacity.

${ }^{18}$ Gómez-Ibáñez and Meyer 1993, ch. 8, 11.
} 
"new and heavily debt-financed toll projects — absent an overwhelming demand profile ... - will require a significant level of public involvement and, perhaps, public investment, to reach investment-grade levels." (p. 44)

\subsection{Transparency}

Most people believe that transparency is inherently valuable in public affairs. It also is needed to facilitate public acceptance of new arrangements. How do public private partnerships rate on transparency, in comparison with traditional public procurement?

On the positive side, the franchising process makes certain planning assumptions explicit. Expectations, commitments, and financial projections must be specified both to define bidding terms and to enable bidders to obtain third-party financing. An example is provided by the 2004 bidding process for a 99-year lease of the Chicago Skyway, which was preceded by the City of Chicago commissioning a first-ever detailed financial projection of the Skyway. ${ }^{19}$

On the negative side, the agreements themselves are highly technical and their provisions difficult to explain to the public. Some details may be proprietary and thus not made public at all. Private firms can bypass rules that would require a public agency to fully expose its decisionmaking. Even when the initial investment is publicly visible, subsequent private transactions, such as refinancing of debt or corporate buyouts of participating firms, may obscure accountability for specific decisions.

Thus transparency is not automatically promoted by private franchising, but it can be if it is an explicit goal. For example, the franchise can specify public availability of certain information; it can also specify conditions under which the sale or refinancing of a lease is permitted, as for example is the practice in France. ${ }^{20}$

\footnotetext{
${ }^{19}$ US GAO (2008, p. 42); Bel and Foote (2009).

${ }^{20}$ Bel and Foote (2009); Joint Transport Research Centre (2008, Annex 1.2).
} 


\subsection{Other Public objectives}

The franchise agreement is a natural place to make specific any other public objectives that might differ from private ones. Examples include environmental practices, links to the larger road network, price stability, and worker protection. Some public objectives, such as safety measures and scenic values, affect private profitability and so will be considered automatically to some extent, but insufficiently if they involve spillover effects beyond what is reflected in users' willingness to pay.

Requiring the franchisee to meet objectives other than those that increase profits will naturally tend to reduce the value of the franchise to the private operator and hence the sizes of private bids for that franchise. This tradeoff is vividly illustrated by Bel and Foote (2009), who estimate the value of various provisions among the franchise terms on five recent road privatizations: two in the US (Chicago Skyway and Indiana Toll Road) and three in France (three parts of its motorway network). The two US franchises were won with bids of 60 and 63 times current earnings, whereas the three French cases had multiples between 12 and $13 .{ }^{21}$

Several factors accounted for this striking difference in contract value. Three of the most important were term length, allowed toll increases, and maximum leverage ratio — factors also highlighted by Forsgren and Macdonald (2005) as affecting franchise value.

The US auctions, which specified very long term lengths, also exhibited much larger spreads between the first- and second-highest bids. This variation may be explained by different bidders assuming different growth rates for operating expenses and traffic. Traffic growth would probably be even more important if these were "greenfield" projects (i.e. new roads) rather than

\footnotetext{
${ }^{21}$ Earnings are here measured net of operating expenses but not of capital charges - specifically, they are "earnings before interest, taxes, depreciation, and amortization" (EBITDA).
} 
"brownfield" (enhancements to existing roads). The dispersion of expectations is a useful reminder of the very real possibility that the winning private firm could be basing its bid on overly optimistic assumptions and, as a result, could encounter subsequent financial problems.

The quantitative effects on bid price of the three factors just mentioned are detailed in Table 1, which summarizes simulations by Bel and Foote (2009). The authors compute the present discounted value of future cash flows, ${ }^{22}$ and assume that 97.3 percent of this value remains after transaction fees. Their base case simulation uses assumptions aimed at explaining the actual winning bid for the Chicago Skyway franchise, whereas other simulations change key parameters in ways approximating their values in the French toll road auctions. As seen in the table, changing any one of the three key parameters has the effect of cutting the bid nearly in half; changing all three simultaneously cuts it by 76 percent (from $\$ 1.83$ to $\$ 0.43$ billion) and lowers the hypothetical ratio of bid price to earnings to 15 . Accounting in addition for the higher cost of capital implied by the French limitation on debt leverage (debt no more than 7 times earnings) cuts the ratio to 12.5 , a nearly exact match to what was observed in the three French concessions. Thus, it is plausible that these four differences between the US and French situations explain most or all of the differences in the resulting ratios of bid price to earnings.

\footnotetext{
${ }^{22}$ Nominal revenues in each year are discounted to the starting year using a nominal annual cost of capital of $9.38 \%$, which is a weighted average of $12.3 \%$ for equity and $8.00 \%$ for debt.
} 


\begin{tabular}{|c|c|c|}
\hline & \multicolumn{2}{|c|}{ Value } \\
\hline & (\$ billions) & $\begin{array}{c}\text { multiple of } \\
\text { earnings }\end{array}$ \\
\hline \multicolumn{3}{|l|}{ Actual bids } \\
\hline Winning bid & 1.83 & 63.1 \\
\hline Second highest bid & 0.70 & 24.1 \\
\hline French toll roads (average) & -- & 12.3 \\
\hline \multicolumn{3}{|l|}{ Simulated bids } \\
\hline Base case (winning bid) & 1.83 & 63.1 \\
\hline Individual parameter adjustments: & & \\
\hline (1) Term length (99 $\rightarrow 23$ years) & 1.03 & 35.6 \\
\hline (2) Toll growth rate $(3.78 \% \rightarrow 2.08 \%)$ & 1.06 & 36.5 \\
\hline (3) Traffic growth rate $(1.23 \% \rightarrow 0.23 \%)$ & 0.93 & 31.9 \\
\hline \multicolumn{3}{|l|}{ Combined parameter adjustments: } \\
\hline$(1)+(2)$ & 0.72 & 25.0 \\
\hline$(1)+(2)+(3)$ & 0.43 & 15.0 \\
\hline $\begin{array}{l}(1)+(2)+(3)+\text { higher cost of capital } \\
(9.38 \% \rightarrow 11.71 \%)\end{array}$ & 0.36 & 12.5 \\
\hline
\end{tabular}

Since three of these four parameters may be regarded as attempts to protect the public interest (through a shorter term length, lower tolls, and more secure financing), most of the difference between the French and US winning bids can be regarded as the cost to French taxpayers of these protections. Are these public benefits worth the costs? This is a difficult question whose answer involves value judgments. But at least the question can be formulated quantitatively, given the information revealed by the bidding process, and thus is open to public discussion.

\subsection{Term length of franchise}

As shown in Section 4.4, the value of a franchise can be substantially enhanced if the franchise covers a long time period, e.g. 50 years or more. This is because the traffic growth expected over the life of the road results in much greater profits in later than earlier years. 
Indeed, almost every new toll road involves plans for a "ramp-up" period of many years in which tolls fail to cover operating expenses, interest, and depreciation. Thus, the ability to attract private finance is greatly enhanced by long term lengths.

But as discussed earlier, a long term makes it more difficult to specify toll rates. By the same argument, other conditions that may be part of a franchise — safety measures, capacity enhancements, maintenance standards, and conditions for adding competing capacity — are more difficult to specify far in advance. How can anyone know what conditions will prevail, or what standards will be deemed appropriate, 75 or 99 years from now?

Another factor is the role of political decisions. A long-term franchise, if enforceable, has the advantage of minimizing political tinkering later on. But what is to prevent a future government from reneging on the terms of the franchise? The court system offers some protection, but changing public interest might produce a consensus that the original terms have become outmoded. Furthermore, the public sector retains other powers, such as regulation and taxation, that can affect the profitability of the franchise. Thus, there is some political risk for the private operator that probably increases with term length.

An auction mechanism proposed by Engel, Fischer, and Galetovic (2001) avoids some of these problems by letting the term length of the lease depend on experience in a specified way. The specific proposal is to base bids on the "least present value of revenues" required. Consider for simplicity the case when a road is expected to be profitable. Instead of submitting bids based on toll rates or on annual profits to be shared, firms would bid on the present value of future revenues they would receive, with present value calculated using one or more interest rates specified as part of the bidding process. The firm proposing the lowest such present value wins the bid and is then allowed to collect revenues until that present value is achieved, after which 
the road reverts to the public sector. This type of auction reduces the impact of uncertain factors in the distant future by letting the time period over which they operate be variable. Specifically, it maintains most of the desirable incentives of other franchise arrangements — to build costeffectively, to provide good service, to keep collection costs down — but it allows the public sector to retain much of the risk due to uncertain traffic levels and future allowed toll rates. If a future government wants to adjust the toll formula or build competing capacity, it can do so without upsetting the franchise so long as the franchisee will still be able to earn enough to eventually reach the specified present value. The same principle can be applied to an unprofitable road if the auction process specifies a specific form for public subsidies.

To summarize, there are advantages to both short- and long-term franchises, the latter probably involving more profit for the franchisee but also more risks for both parties. A variableterm contract, such as that offered in an auction based on least prevent value of revenues, is an attractive alternative.

\subsection{Renegotiations and bail-outs}

Franchise agreements sometimes lead to renegotiations when conditions differ from those anticipated by one or both parties. Reasons could include impending bankruptcy, unanticipated congestion, changes in political governance, or adverse publicity over some aspect of the publicprivate relationship. In Spain, renegotiations are said to be an expected normal part of the franchise process, allowing provisions to be "rebalanced" to reflect new information (US GAO 2008, p. 47). The UK government changed its mind about private operation of the Skye Bridge in Scotland, and ultimately purchased the bridge from the private operator. In the US, impending bankruptcy forced reconsideration of the terms of the Dulles Greenway concession in Virginia, 
and public outcry over a non-compete provision caused the franchise for the "91 Express Lanes" in California to be bought out by the local public transportation authority. Such renegotiations can add substantially to the transactions costs of PPPs, which are already quite high — perhaps 3 percent of project costs as opposed to about 1 percent for public procurement (Välilä 2005, p. 109).

Engel, Fischer, and Galetovic (2003) argue that prevalent renegotiations of highway franchises in Latin America prevented the realization of hoped-for benefits of highway privatization there. Unlike the original franchise arrangements, renegotiations tended to take place outside of public view. Furthermore:

Such renegotiations negate the public benefits of private highways by giving an advantage to firms with political connections, limiting the risk of losses, and reducing the incentives to be effective and cautious in assessing project profitability. (p. 131)

They attribute these renegotiations mainly to two factors. First, governments enacted and implemented privatization policies in haste, failing to have sound regulatory mechanisms in place beforehand. Second, the use of fixed-term contracts caused all the demand risk to be borne by the private party, which as we have seen makes it subject to factors outside of its control. Another factor, which may be endemic, was that highway plans tended to be made during economic booms, causing a systematic tendency to overestimate future revenues through extrapolation from recent trends. Guasch (2004) provides further details.

The prospect of renegotiations lends weight to the importance of designing good contracts to begin with, and suggests that such contracts may want to specify a framework for subsequent renegotiations that leaves neither party at the mercy of the other. 


\section{Conclusion}

We have seen that private provision of highway services offers potential benefits in many situations, but to realize them requires considerable public involvement and sophistication.

One such benefit is a wider range of funding sources available for investments in highway infrastructure, due to fiscal and political constraints on governments and the availability of private funds seeking time profiles and risk structures compatible with toll roads. Furthermore, private firms can usually react more quickly to opportunities than can the public sector, and thus can help when there is a backlog of needed infrastructure investments.

Another benefit is risk-sharing; but private provision is not simply a way for the public sector to shed risk. Rather, through the franchising process it is possible to specify terms that allow each entity to bear the risk it is most suited for and to give each party incentives to minimize the adverse consequences of uncertain events, either by preventing them or by adapting to them. As for the remaining uncertainty, there is no strong reason to believe that either the private or the public sector has a general advantage in bearing it, although one may have an advantage in specific situations.

A third benefit is that private firms may well realize some cost efficiencies relative to the public sector. But such efficiencies remain unproven and are probably less in highways than in some other sectors. Private partnerships do perform more closely to the original budgets and time schedules, but this does not necessarily imply cost savings because those plans are themselves affected by whether the provider is public or private.

Because road services cannot plausibly constitute a competitive market, any use of private operators needs to be accompanied by some restraint on market power. Such restraint can be achieved by toll regulation, but doing so tends to eliminate desirable price flexibility and also 
requires unrealistic amounts of information about future conditions. A more promising approach is an auction that specifies a particular financial target, the amount of which is the subject of the firms' bids, allowing toll rates and the duration of the franchise to adjust to achieve the target that is agreed on. Other public concerns such as safety, environmental goals, service quality, and financial stability of the private provider can also be addressed in a franchise agreement.

Private provision of express lanes, in direct competition with a publicly owned free road, is a special case. The social benefit depends critically on balancing the traffic between the two roadways, so as to allow the express lanes to offer a premium service (especially beneficial with heterogeneous users) but not to produce too much congestion on the free road. In most cases, the public interest is best served if express lanes are priced below a level that would cover their construction cost.

More generally, private highway provision can produce useful experimentation with pricing structures because a private operator has an incentive to adopt time-of-day variation in toll rates. Such experiments can provide valuable lessons provided the operator is given some pricing flexibility. This may well prove to be the most important benefit, because studies have shown that the crude pricing now typical of roads is substantially limiting their efficiency in meeting mobility objectives. 


\section{References}

Allen Consulting Group (2007) Performance of PPPs and Traditional Procurement in Australia, Melbourne, Australia: Allen Consulting Group.

http://www.infrastructure.org.au/research/pdf/InfrastructurePartnershipsAustralia PPPReport Fi $\underline{\text { nal.pdf }}$

Averch, Harvey, and Leland L. Johnson (1962), "Behavior of the Firm under Regulatory Constraint," American Economic Review, 52(5): 1052-1069.

Bel, Germà, and John Foote (2009), "Tolls, Terms and Public Interest in Road Concessions Privatization: A Comparative Analysis of Recent Transactions in the USA and France," Transport Reviews, forthcoming.

de Palma, André, and Robin Lindsey (2002) "Private Roads, Competition, and Incentives To Adopt Time-Based Congestion Tolling," Journal of Urban Economics, 52: 217-241.

Dewatripont, Mathias, and Patrick Legros (2005) "Public-Private Partnerships: Contract Design and Risk Transfer," EIB Papers, 10: 120-145. Luxembourg: European Investment Bank. http://www.eib.org/attachments/efs/eibpapers/eibpapers_2005 v10 n01/eibpapers_2005 v10 n0 1 a 05 en.pdf

Engel, Eduardo M., Ronald Fischer, and Alexander Galetovic (2001) "Least-Present-Value-ofRevenue Auctions and Highway Franchising,” Journal of Political Economy, 109: 993-1020.

Engel, Eduardo M., Ronald Fischer, and Alexander Galetovic (2003) "Privatizing Highways in Latin America: Fixing What Went Wrong," Economía, 4: 129-158.

Forsgren, Kurt, and Laura A. Macdonald (2005) "Can Public-Private Partnerships Advance U.S. Roadway Infrastructure Development?” Standard \& Poor's PPP Credit Survey 2005, May, pp. 41-49.

Gómez-Ibáñez, José A. (2003) Regulating Infrastructure: Monopoly, Contracts, and Discretion, Cambridge, Mass.: Harvard University Press.

Gómez-Ibáñez, José A., and John R. Meyer (1993) Going Private: The International Experience with Transport Privatization, Washington, D.C.: Brookings Institution.

Guasch, J. Luis (2004) Granting and Renegotiating Infrastructure Concessions: Doing it Right, Washington, D.C.: World Bank. http://info.worldbank.org/etools/PPPIPortal/eLibrary3.asp?ObjectID $=240056 \&$ ParentTopicID $=2332 \&$ ParentTopicID $=2332 \& T=1$

Guthrie, Graeme (2006) "Regulating Infrastructure: the Impact on Risk and Investment," Journal of Economic Literature, 44: 925-972. 
Irwin, Timothy C. (2007) Government Guarantees: Allocating and Valuing Risk in Privately Financed Infrastructure Projects, Washington, D.C.: The World Bank. http://siteresources.worldbank.org/INTSDNETWORK/Resources/Government_Guarantees.pdf

Joint Transport Research Centre (2008) Transport Infrastructure Investment: Options for Efficiency, Paris: Organisation for Economic Co-operation and Development and International Transport Forum.

Karlaftis, Matthew G. (2008) "Privatisation, regulation and competition: A Thirty-Year Retrospective on Transit Efficiency," in Andreas Kopp, ed., Privatisation and Regulation of Urban Transit Systems, Proceedings of Roundtable 141, Organisation for Economic Cooperation and Development and Transport Research Forum, Paris, pp. 67-108.

Klein, Michael (1997) “The Risk Premium for Evaluating Public Projects," Oxford review of Economic Policy, 13(4): 29-42.

Kleven, Henrik Jacobsen and Claus Thustrup Kreiner (2006) "The marginal cost of public funds: Hours of work versus labor force participation," Journal of Public Economics, 90: 1955-1973.

Laffont, Jean-Jacques and Jean Tirole (1993) A Theory of Incentives in Procurement and Regulation, Cambridge, MA: MIT Press.

Lee, Douglass B., Jr. (2008) "Toward the Evaluation of Value Pricing," Transportation Research Record: Journal of the Transportation Research Board, 2079: 71-78.

Nash, Christopher A. (2005) "Privatization in Transport," in Kenneth J. Button and David A. Hensher (eds.), Handbook of Transport Strategy, Policy and Institutions, Amsterdam and Boston: Elsevier, pp. 97-113.

Parry, Ian W.H., and Wallace E. Oates (2000) "Policy Analysis in the Presence of Distorting Taxes," Journal of Policy Analysis and Management, 19(4): 603-613.

Parry, Ian W.H., and Kenneth A. Small (2005) "Does Britain or The United States Have the Right Gasoline Tax?" American Economic Review, 95: 1276-1289.

Perry, James L., Timlynn Babitsky, and Hal Gregersen (1988) "Organizational Form and Performance in Urban Mass Transit," Transport Reviews, 8: 125-143.

Poole, Robert W., Jr. (2006) Reducing Congestion in Atlanta: A Bold New Approach to Increasing Mobility, Policy Study 351, Reason Foundation, Los Angeles.

http://www.reason.org/ps351.pdf

Preston, John (2005) "Tendering of Services," in: Kenneth J. Button and David A. Hensher, eds., Handbook of Transport Strategy, Policy and Institutions, Amsterdam: Elsevier, pp. 65-81. 
Santos, Georgina, ed. (2004) Road Pricing: Theory and Evidence. Volume 9 of Research in Transportation Economics, Amsterdam and Oxford, UK: Elsevier.

Small, Kenneth A. (1999) "Economies of scale and self-financing rules with noncompetitive factor markets," Journal of Public Economics, 74: 431-450.

Small, Kenneth A., and Erik T. Verhoef (2007) The Economics of Urban Transportation, London and New York: Routledge.

Small, Kenneth A., Clifford Winston and Jia Yan (2005) "Uncovering the Distribution of Motorists' Preferences for Travel Time and Reliability," Econometrica 73: 1367-1382.

Small, Kenneth A. and Jia Yan (2001) "The Value of 'Value Pricing' of Roads: Second-Best Pricing and Product Differentiation," Journal of Urban Economics, 49: 310-336.

Spiller, Pablo T. (2008) “An Institutional Theory of Public Contracts: Regulatory Implications," Working paper 14152, Cambridge, Mass.: National Bureau of Economic Research.

Sullivan, Edward, et al. (2000) Continuation Study to Evaluate the Impacts of the SR91 ValuePriced Express Lanes: Final Report, San Luis Obispo, CA: California Polytechnic State University, San Luis Obispo. http://ceenve.calpoly.edu/sullivan/sr91/sr91.htm

Sullivan, Edward C. (2006) "HOT Lanes in Southern California," in: Gabriel Roth, ed., Street Smart: Competition, Entrepreneurship, and the Future of Roads, New Brunswick, N.J. and London: Transaction Publishers, pp. 189-223.

US DOT (2008a) "Urban Partnerships," part of website of FightGridlockNow.gov, US Department of Transportation, Washington, D.C. http://www.upa.dot.gov.

US DOT (2008b) "Express Lanes Demonstration Program," US Department of Transportation, Washington, D.C. http://ops.fhwa.dot.gov/tolling_pricing/express_lanes.htm

US FHWA (2008) Highway Statistics 2007. US Federal Highway Administration, Washington, D.C. http://www.fhwa.dot.gov/policyinformation/statistics/2007/

US GAO (2008) Highway Public-Private Partnerships: More Rigorous Up-front Analysis Could Better Secure Potential Benefits and Protect the Public Interest, Report GAO-08-44, Washington, D.C.: United States Government Accountability Office, February. http://www.gao.gov/new.items/d0844.pdf

Välilä, Timo, "How expensive are cost savings? On the Economics of Public-Private Partnerships," EIB Papers, 10: 94-119. Luxembourg: European Investment Bank. http://www.eib.org/attachments/efs/eibpapers/eibpapers_2005_v10_n01/eibpapers_2005_v10_n0 1_a04_en.pdf 
Verhoef, Erik T., and Kenneth A. Small (2004) "Product Differentiation on Roads: Constrained Congestion Pricing with Heterogeneous Users," J. Transport Econ. and Policy, 38: 127-156.

Zmud, Johanna, and Carlos Arce (2008) Compilation of Public Opinion Data on Tolls and Road Pricing, National Cooperative Highway Research Program Synthesis 377, Washington, D.C.: Transportation Research Board. 